\title{
Development of Efficient, Reproducible and Stable Agrobacterium- -Mediated Genetic Transformation of Five Potato Cultivars
}

\author{
Allah Bakhsh*(0) \\ Department of Agricultural Genetic \\ Engineering, Faculty of Agricultural \\ Sciences and Technologies, Nigde \\ Omer Halisdemir University, 51240 \\ Nigde, Turkey
}

Received: 25 December 2018 Accepted: 6 March 2020

\footnotetext{
*Corresponding author:

E-mail:abthebest@gmail.com, allah.bakhsh@nigde.edu.tr
}

\begin{abstract}
SUMMARY
The developments in transformation technology have enabled the scientists to incorporate, mutate or substitute gene(s) leading to a particular trait; advancing it to a point where only few technical limitations remain. Genotype dependency and explant types are important factors affecting transformation efficiency in potato. In the present study, a rapid, reproducible and stable Agrobacterium-mediated transformation procedure in potato was developed by a combination of different plant growth regulators. Leaf discs and internodal explants of five cultivars of potato, i.e. Lady Olympia, Granola, Agria, Désirée and Innovator were infected with Agrobacterium tumefaciens strain LBA4404 containing pBIN19 expression vector with $\beta$-glucuronidase gus $A$ gene under the control of $35 \mathrm{~S} \mathrm{CaMV} \mathrm{promoter.} \mathrm{Kanamycin}$ was used as plant selectable marker for screening of primary transformants at concentration of $100 \mathrm{mg} / \mathrm{L}$. Both explants responded positively; internode being more suitable explant for better transformation efficiency. Based on GUS histochemical assay, the transformation efficiency was $22,20,18.6,15$ and $10 \%$ using the internodal explant, and 15, 12, 17, 8 and $6 \%$ using leaf discs as explant in Lady Olympia, Granola, Agria, Désirée and Innovator respectively. Furthermore, PCR assays confirmed the presence of gus $A$ and nptll genes in regenerated plants. The molecular analysis in succeeding progeny showed proper integration and expression of both genes. The results suggest Lady Olympia as the best cultivar for future transformation procedures. Overall, the short duration, rapidity and reproducibility make this protocol suitable for wider application of transgenic potato plants.
\end{abstract}

Key words: potato genetic transformation, genotypes, plant growth regulators, cost-effective protocol

\section{INTRODUCTION}

Potato (Solanum tuberosum L.) is a primary non-cereal food crop and ranks 4th in the world because of its high productivity, following corn (Zea mays L.), rice (Oryza sativa L.) and wheat (Triticum aestivum $\mathrm{L}$.) in terms of yield, acreage and value (1). Potato is considered one of the auspicious crops to overcome the challenges of poverty and hunger worldwide (2). Turkey is an important potato producing country globally. Potato accounts for $3 \%$ of the gross national agricultural product, $3.1 \%$ in 27 EU countries, therefore has a significant impact on Turkish economy (3).

Potato is affected by viral, bacterial and fungal diseases, and nematodes (4). The crop is affected by pathogens at different stages of growth, from the preharvest to the postharvest (5). Using modern technologies, the researchers have incorporated different traits related to biotic and abiotic stress tolerance in potato. These technologies transcend traditional plant breeding methods by allowing the rapid and predictable gene transfer across the species boundaries. None of the commercial transgenic potatoes is being planted until the completion of regulatory and safety process and later on commercial release of Innate ${ }^{\mathrm{TM}} 1.0$ potatoes in Atlantic, Ranger Russet and Russet Burbank cultivars with low acrylamide potential and black spot bruise resistance traits by J.R. Simplot Company (6).

Agrobacterium-mediated genetic transformation is widely used for the introduction of foreign gene(s) into dicots (7). There are several studies that report the successful 
incorporation of foreign gene(s) in potato using Agrobacterium-mediated transformation (8-10). Using two-stage transformation protocol with leaf explants, Cingel et al. (9) successfully reported high shoot regeneration efficiency (84-89\% for Dragacevka and 60-68 \% for Jelica cultivar compared to 76-86 \% for Desiree) by combining procedures of Webb and Wenzler. However, from a broader perspective, these published procedures face limitations of lower transformation frequency, genotype dependency or somaclonal variations mainly due to prolonged tissue culture conditions, thus resulting in lower yield of stable transgenic plants (11).

Development of an efficient and reproducible plant transformation and regeneration protocol is a prerequisite for genetic transformation studies of plants (12). The successful plant transformation requires a proper DNA delivery system, a plant regeneration system, and a selection system to recognize the transgenic cells. As evident from scientific literature, an efficient and reproducible transformation protocol in potato is still lacking; therefore, by combining different already reported protocols with some modifications, the present study attempts to optimize a cost-effective and reproducible transformation protocol for five different potato cultivars, i.e. Lady Olympia, Agria, Granola, Désirée and Innovator.

\section{MATERIALS AND METHODS}

\section{Potato cultivars}

The present study uses five commercial cultivars (Lady Olympia, Agria, Granola, Désirée and Innovator) of potato growing zone in Turkey for genetic transformation. These cultivars have been selected on the basis of their agronomic characteristics and good yield potential in Central Anatolian Region, Turkey.

\section{Establishment of shoot cultures}

Tuber sprouts of the aforementioned potato cultivars were surface sterilized as described by Bakhsh et al. (13) for sweet potato. The in vitro shoot cultures of cultivars obtained from tuber sprouts were propagated monthly as nodal cultures by incubating on medium containing Murashige and Skoog (MS) (14) mineral salts, $3 \%$ sucrose and $8 \mathrm{~g} / \mathrm{L}$ plant agar. The $\mathrm{pH}$ of the medium was adjusted to 5.7-5.8 prior to autoclaving. All chemicals (plant agar, MS salts and sucrose) used in this study were purchased from Duchefa Biochemie B.V. (Haarlem, the Netherlands) and Sigma-Aldrich Co., Merck (St. Louis, MO, USA). Cultures were grown under controlled conditions in a growth room with a $16 / 8 \mathrm{~h}$ light/dark photoperiod, $47 \mu \mathrm{mol} /\left(\mathrm{m}^{-2} \cdot \mathrm{s}\right)$ irradiance at the culturing surface provided by $58 \mathrm{~W}$ fluorescent tubes and temperature $(25 \pm 2)^{\circ} \mathrm{C}$.

\section{Agrobacterium-mediated transformation}

Agrobacterium tumefaciens strain LBA4404 harbouring pBIN19 binary vector containing gus $A$ ( $\beta$-glucuronidase) gene under the control of 355 promoter was used (Fig. 1). The reporter gene ( $g u s A$ ) was interrupted by an intronic sequence to deduce expression only from eukaryotic cells. The glycerol stocks were streaked on Luria-Bertani (LB) agar plates containing kanamycin and rifampicin (Sigma-Aldrich Chemicals Co., Merck) each at concentration of $50 \mathrm{mg} / \mathrm{L}$. One colony
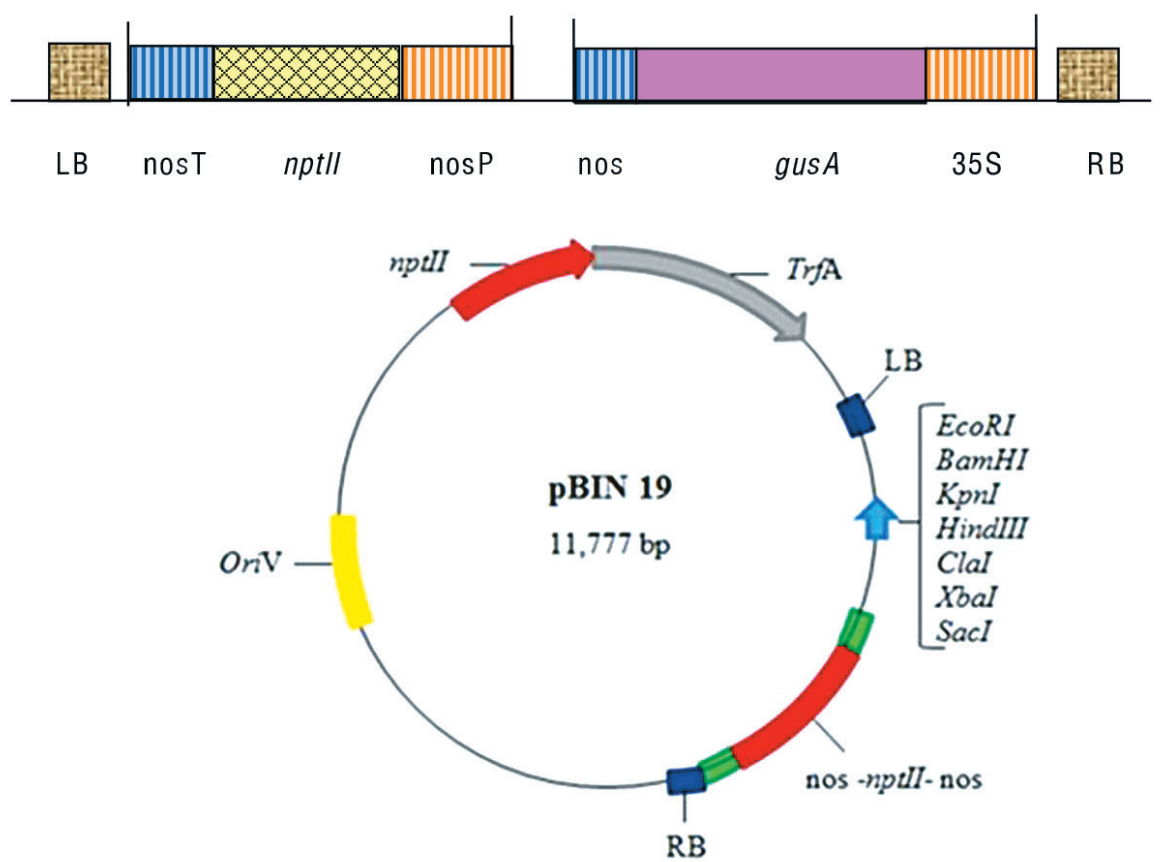

Fig. 1. Description of pBIN19 binary vector containing gusA and neomycin phosphotransferase (nptII) driven by cauliflower mosaic virus (CaMV35S) promoter and nopaline synthase (NOS) terminator in between right and left border. The construct has nptll gene that encodes resistance to kanamycin, used as a plant selectable marker at $\gamma=100 \mathrm{mg} / \mathrm{L}$ 
from a plate was inoculated in LB broth supplemented with appropriate concentrations of antibiotics. The bacterial culture was incubated in shaking incubator (ISF1-X; Adolf Kühner AG, Basel, Switzerland) at $28^{\circ} \mathrm{C}$ overnight.

The explants were inoculated with Agrobacterium suspension $\left(A_{600 \mathrm{~nm}}=0.8\right)$ for $20 \mathrm{~min}$ with gentle shaking at 180 rpm in liquid medium without antibiotic followed by incubation on cocultivation medium for approx. three days. Cocultivation medium contained MS salts including vitamins, $3 \%$ sucrose, 7-8 g/L agar and $100 \mu \mathrm{M}$ acetosyringone (Sigma-Aldrich Chemicals Co., Merck). The $\mathrm{pH}$ of the medium was adjusted to 5.8. After cocultivation, the explants were blotted dry on a filter paper and cultured with three different hormonal combinations on three regeneration selection media (RSM) as three concurrent experiments, i.e. RSM1 consisting of MS supplemented with trans-zeatin $2 \mathrm{mg} / \mathrm{L}+$ naphthaleneacetic acid (NAA) $0.2 \mathrm{mg} / \mathrm{L}, \mathrm{RSM} 2$ with benzyladenine (BA) $2 \mathrm{mg} / \mathrm{L}+\mathrm{NAA} 0.2 \mathrm{mg} / \mathrm{L}+$ gibberellic acid (GA3) $0.1 \mathrm{mg} / \mathrm{L}$, and RMS3 with BA $2 \mathrm{mg} / \mathrm{L}+\mathrm{NAA} 0.2 \mathrm{mg} / \mathrm{L}$ +trans-zeatin $2 \mathrm{mg} /$ L+GA3 $0.1 \mathrm{mg} / \mathrm{L}$. Regeneration selection media were used for both callus induction and shoot induction. The plant growth regulators used were purchased from Duchefa Biochemie B.V. Duocid 300 mg/L (Pfizer, Istanbul, Turkey) and kanamycin 100 $\mathrm{mg} / \mathrm{L}$ were also added to each RSM to eliminate excessive growth of Agrobacterium and for selection of primary transformants, respectively.

The in vitro cultured shoots reaching a length of 2-3 $\mathrm{cm}$ were excised and transferred to large magenta boxes (107 mm $\times 94 \mathrm{~mm} \times 96 \mathrm{~mm}$ ) containing MS medium with kanamycin $100 \mathrm{mg} / \mathrm{L}$ to continue selection pressure. The plantlets with well-established roots were shifted to soil comprising peat and perlite mix (3:1) in a greenhouse to obtain tubers for further studies.

\section{GUS histochemical assay}

GUS histochemical assays were performed to test the functionality of gusA gene at different steps of transformation. To accomplish the task, GUS buffer containing $10 \mathrm{mg} / \mathrm{L}$ X-Gluc, 10 mM EDTA, 100 mM NaH ${ }_{2} P_{4}, 0.1 \%$ Triton X-100 and $50 \%$ methanol (Sigma-Aldrich Chemicals Co., Merck) was prepared. The $\mathrm{pH}$ of the buffer was maintained at 8 . The resistant calli, regenerated shoots and plantlets were incubated in this buffer overnight at $37^{\circ} \mathrm{C}$. Furthermore, samples were destained by adding $70 \%$ ethanol to 2-mL Eppendorf tubes. The transformation efficiency in cultivars was calculated based on the GUS activity.

\section{PCR analysis}

The putative transgenic plants belonging to different cultivars were analyzed by PCR assays to confirm the presence of gusA and nptll genes with introduced T-DNA. For this purpose, genome DNA was isolated using Nucleo Spin ${ }^{\circledast}$ Plant II Kit (Macherey-Nagel GmbH \& Co., Düren, Germany) and then PCR assays were carried out using gene-specific primer to amplify internal fragments of the aforementioned genes. PCR reaction was carried out in a total reaction volume of $20 \mu \mathrm{L}$ containing $1 \times$ reaction buffer, $10 \mathrm{ng}$ DNA template, $1.5 \mathrm{mM} \mathrm{MgCl}_{2}, 0.1 \mathrm{mM}$ dNTPs mix, $0.5 \mu$ M each primer and one unit Taq DNA polymerase (Thermo Scientific Inc., Waltham, MA, USA). Furthermore, the reaction was carried out using initial denaturation at $94^{\circ} \mathrm{C}$ for 4 min followed by 35 cycles of denaturation at $94^{\circ} \mathrm{C}$ for 30 $\mathrm{s}$, annealing at $55^{\circ} \mathrm{C}$ (gusA and $\left.n p t / l\right)$ and $65^{\circ} \mathrm{C}$ (chvA) for $30 \mathrm{~s}$, extension at $72{ }^{\circ} \mathrm{C}$ for $30 \mathrm{~s}$, followed by a final extension at 72 ${ }^{\circ} \mathrm{C}$ for $7 \mathrm{~min}$. In all PCR reactions, pBIN19 plasmid was used as positive control whereas the DNA isolated from untransformed plants was used as negative control. Supplementary Table S1 contains information about primer sequences, annealing temperature and product size.

Nester (15) reported that Agrobacterium infection of plant host depends on activation of chromosomal virulence genes along with vir gene. Since chvA gene has a role in the attachment of bacteria to the host cell, the primary transformants containing any Agrobacterium contamination (latency) were tested using gene-specific primers.

The transgenic potato plants positive for the introduced gene (based on PCR and GUS histochemical assays) were grown in a greenhouse, tubers were harvested and planted again to confirm the presence and expression of gus $A$ in succeeding tuber progeny. All statistical analyses were performed with Statistix v. 8.1 software (16). Significance of variance was determined with the one-way ANOVA $(p<0.05)$ followed by least significance difference (LSD) test.

\section{RESULTS AND DISCUSSION}

The scientific literature reports the use of Agrobacterium-mediated genetic transformation system for the introduction of gene(s) encoding traits of economic importance in crop plants $(17,18)$. Agrobacterium tumefaciens strain LB4404 has been found more infective and efficient than other strains for transformation especially in dicots (19). In the present study, strain LBA4404 harbouring recombinant plasmid pBIN19 was used to optimize the transformation protocol in potato cultivars under study.

In optimization experiments, three different regeneration selection media (RSM) were used for leaf discs and internodal explants (Table 1 and Table 2). Fig. S1 shows different steps of genetic transformation. Leaf disc explants cultured on RSM3 showed good results compared to other two selection media, although the response of cultivars also varied. The maximum number of resistant calli was observed in Lady Olympia cultivar followed by Désirée, Agria, Granola and Innovator (Table 1). The average number of shoots per explant was high in Désirée, followed by Lady Olympia, Agria, Granola and Innovator. The response of internodal explants cultured on RSM3 was also more encouraging than on the other two selection media. The maximum percentage of resistant callus development was observed in Désirée, followed by Lady Olympia, Agria, Granola and Innovator, whereas average number of shoots per explant was high in Désirée and 
Table 1. Study of the influence of different regeneration selection media (RSM) on the regeneration of potato cultivars using leaf discs as explant

\begin{tabular}{|c|c|c|c|c|c|c|c|c|c|}
\hline \multirow[b]{2}{*}{ Cultivar } & \multicolumn{3}{|c|}{ RSM1 } & \multicolumn{3}{|c|}{ RSM2 } & \multicolumn{3}{|c|}{ RSM3 } \\
\hline & $N$ (explant) & $\begin{array}{c}\text { Callus } \\
\text { induction/\% }\end{array}$ & $\begin{array}{l}\bar{N}(\text { shoot }) / \\
\bar{N}(\text { explant })\end{array}$ & $N$ (explant) & $\begin{array}{c}\text { Callus } \\
\text { induction/\% }\end{array}$ & $\begin{array}{l}\bar{N}(\text { shoot }) / \\
\bar{N}(\text { explant })\end{array}$ & $N$ (explant) & $\begin{array}{c}\text { Callus } \\
\text { induction/\% }\end{array}$ & $\begin{array}{c}\bar{N}(\text { shoot }) / \\
\bar{N}(\text { explant })\end{array}$ \\
\hline Lady Olympia & 300 & $70.0^{\mathrm{a}}$ & $1.80^{\mathrm{ab}}$ & 300 & $76.5^{\mathrm{a}}$ & $3.55^{\mathrm{a}}$ & 300 & $82.2^{\mathrm{a}}$ & $4.75^{\mathrm{ab}}$ \\
\hline Désirée & 300 & $60.0^{b}$ & $2.20^{\mathrm{a}}$ & 300 & $60.0^{c}$ & $2.50^{\mathrm{a}}$ & 300 & $80.0^{a}$ & $5.50^{\mathrm{a}}$ \\
\hline Agria & 300 & $61.5^{\mathrm{b}}$ & $1.25^{\mathrm{ab}}$ & 300 & $66.6^{b}$ & $1.20^{\mathrm{b}}$ & 300 & $70.5^{\mathrm{b}}$ & $2.70^{c}$ \\
\hline Granola & 300 & $42.2^{c}$ & $0.00^{\mathrm{b}}$ & 300 & $44.0^{d}$ & $0.80^{\mathrm{b}}$ & 300 & $45.6^{c}$ & $2.55^{\mathrm{bc}}$ \\
\hline Innovator & 300 & $30.1^{d}$ & $0.00^{\mathrm{b}}$ & 300 & $32.5^{\mathrm{e}}$ & $0.00^{b}$ & 300 & $32.0^{d}$ & $1.50^{c}$ \\
\hline
\end{tabular}

Mean values followed by the same letter in superscript within a column are not significantly different according to LSD test at $p=0.05$ ${ }^{*} \gamma($ kanamycin $)=100 \mathrm{mg} / \mathrm{L}$ and $\gamma$ (duocid) $=300 \mathrm{mg} / \mathrm{L}$ were added to each RSM medium for plant selection and to inhibit bacterial growth, respectively. $R S M 1=$ trans-zeatin $2 \mathrm{mg} / \mathrm{mL}$ +naphthaleneacetic acid (NAA) $0.2 \mathrm{mg} / \mathrm{L}, \mathrm{RSM} 2=$ benzylademine (BA) $2 \mathrm{mg} / \mathrm{L}+\mathrm{NAA} 0.2 \mathrm{mg} /$ L+gibberellic acid (GA3) $0.1 \mathrm{mg} / \mathrm{L}, \mathrm{RSM} 3=\mathrm{BA} 2 \mathrm{mg} / \mathrm{mL}+\mathrm{NAA} 0.2 \mathrm{mg} / \mathrm{L}+$ trans-zeatin $2 \mathrm{mg} / \mathrm{mL}+\mathrm{GA} 30.1 \mathrm{mg} / \mathrm{L}$

Table 2. Study of the influence of different regeneration selection media (RSM) on the regeneration of potato cultivars using internodes as explant

\begin{tabular}{|c|c|c|c|c|c|c|c|c|c|}
\hline \multirow[b]{2}{*}{ Cultivar } & \multicolumn{3}{|c|}{ RSM1 } & \multicolumn{3}{|c|}{ RSM2 } & \multicolumn{3}{|c|}{ RSM3 } \\
\hline & $N$ (explant) & $\begin{array}{c}\text { Callus } \\
\text { induction/\% }\end{array}$ & $\begin{array}{l}\bar{N} \text { (shoot)/ } \\
\bar{N} \text { (explant) }\end{array}$ & $N$ (explant) & $\begin{array}{c}\text { Callus } \\
\text { induction/\% }\end{array}$ & $\begin{array}{c}\bar{N} \text { shoot }) / \\
\bar{N} \text { (explant) }\end{array}$ & $N$ (explant) & $\begin{array}{c}\text { Callus } \\
\text { induction/\% }\end{array}$ & $\begin{array}{l}\bar{N}(\text { shoot }) / \\
\bar{N} \text { (explant) }\end{array}$ \\
\hline Lady Olympia & 300 & $63.0^{\mathrm{b}}$ & $1.35^{\mathrm{ab}}$ & 300 & $58.5^{\mathrm{b}}$ & $1.80^{\mathrm{ab}}$ & 300 & $79.5^{\mathrm{a}}$ & $4.50^{\mathrm{ab}}$ \\
\hline Désirée & 300 & $60.0^{c}$ & $2.50^{\mathrm{a}}$ & 300 & $70.0^{\mathrm{a}}$ & $2.50^{\mathrm{a}}$ & 300 & $80.0^{\mathrm{a}}$ & $5.50^{\mathrm{a}}$ \\
\hline Agria & 300 & $75.2^{\mathrm{a}}$ & $2.20^{\mathrm{a}}$ & 300 & $71.5^{\mathrm{a}}$ & $1.20^{\mathrm{ab}}$ & 300 & $74.5^{\mathrm{b}}$ & $5.50^{\mathrm{a}}$ \\
\hline Granola & 300 & $48.7^{d}$ & $0.45^{\mathrm{b}}$ & 300 & $52.0^{c}$ & $0.00^{\mathrm{b}}$ & 300 & $55.5^{c}$ & $3.00^{\mathrm{bc}}$ \\
\hline Innovator & 300 & $27.5^{e}$ & $0.00^{\mathrm{b}}$ & 300 & $32.5^{\mathrm{d}}$ & $0.00^{\mathrm{b}}$ & 300 & $36.2^{\mathrm{d}}$ & $2.50^{c}$ \\
\hline
\end{tabular}

Mean values followed by the same letter in superscript within a column are not significantly different according to LSD test at $p=0.05$ ${ }^{*} \gamma($ kanamycin $)=100 \mathrm{mg} / \mathrm{L}$ and $\gamma$ (duocid) $=300 \mathrm{mg} / \mathrm{L}$ were added to each RSM medium for plant selection and to inhibit bacterial growth, respectively. $R S M 1=$ trans-zeatin $2 \mathrm{mg} / \mathrm{mL}$ +naphthaleneacetic acid (NAA) $0.2 \mathrm{mg} / \mathrm{L}, \mathrm{RSM} 2=$ benzylademine (BA) $2 \mathrm{mg} / \mathrm{L}+\mathrm{NAA} 0.2 \mathrm{mg} /$ L+gibberellic acid (GA3) $0.1 \mathrm{mg} / \mathrm{L}, \mathrm{RSM} 3=\mathrm{BA} 2 \mathrm{mg} / \mathrm{mL}+\mathrm{NAA} 0.2 \mathrm{mg} / \mathrm{L}+$ trans-zeatin $2 \mathrm{mg} / \mathrm{mL}+\mathrm{GA} 30.1 \mathrm{mg} / \mathrm{L}$

Agria, followed by Lady Olympia, Granola and Innovator (Table 2). Both explants showed encouraging response of callus induction and its further proliferation. The shoot regeneration worked better from internodes of certain cultivars, while for others it worked better from leaf discs. Shoot development using internodal and leaf explants of Lady Olympia and Désirée was not significantly different on RSM3; however, it was different when compared to other cultivars. Almost $100 \%$ rooting was observed in regenerated shoots. The well rooted regenerated plants were transferred to the greenhouse and subjected to GUS histochemical assays at different stages.

GUS histochemical analysis revealed the functionality of gusA gene in primary transformants at different stages (Fig. S2). Based on GUS assay results, higher transformation efficiency was recorded in Lady Olympia and Agria than in other cultivars in both explants. Encouraging and efficient transformation efficiency was recorded in all cultivars, although internodal explants proved to be more productive (Fig. 2). The combination of the Agrobacterium and the continuous selection pressure caused by kanamycin resulted in putatively transformed plants of each cultivar.

Previous studies by Banerjee et al. (20), Ducreux et al. (21) and De Block (22) have established organogenesis in potato using NAA, zeatin and GA3 combinations; however, the addition of $B A$ and high concentration of zeatin in this study resulted in higher regeneration frequency that led to increased number of shoots per explants than other regeneration selection media.
Genotype dependency in potato cultivars has also been observed when subjected to Agrobacterium transformation (23). Some of the cultivars are more amenable to transformation than others. Various factors, such as the type of vector and Agrobacterium strain, explant type, and varietal genetic background can affect the efficiency of Agrobacterium-mediated transformation in crops $(9,12,18,19,24)$. The putative transgenic plants (210 in total number) of different cultivars were acclimatized to the greenhouse and confirmed by PCR assays. In this study, encouraging results were recorded from cultivars indicating the genotype independency to certain extent.

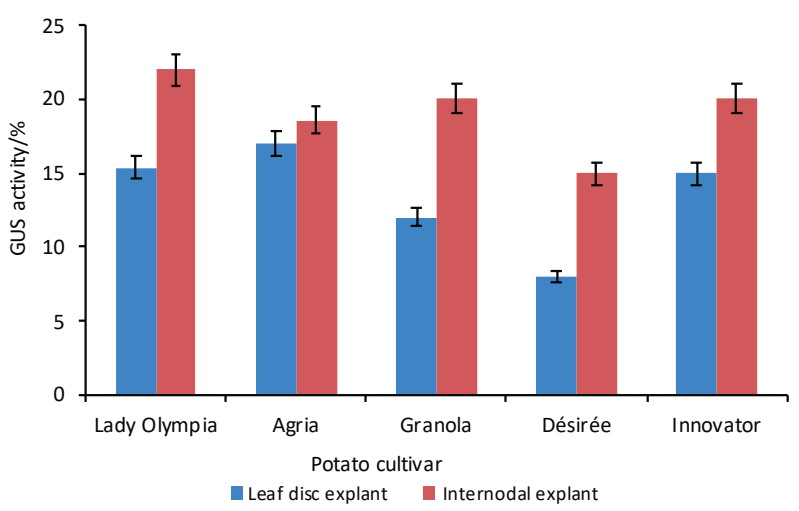

Fig. 2. Transformation efficiency was recorded in putative transgenic shoots of cultivars Lady Olympia, Agria, Granola, Désirée and Innovator based on GUS histochemical assay using leaf disc and internodal explants 


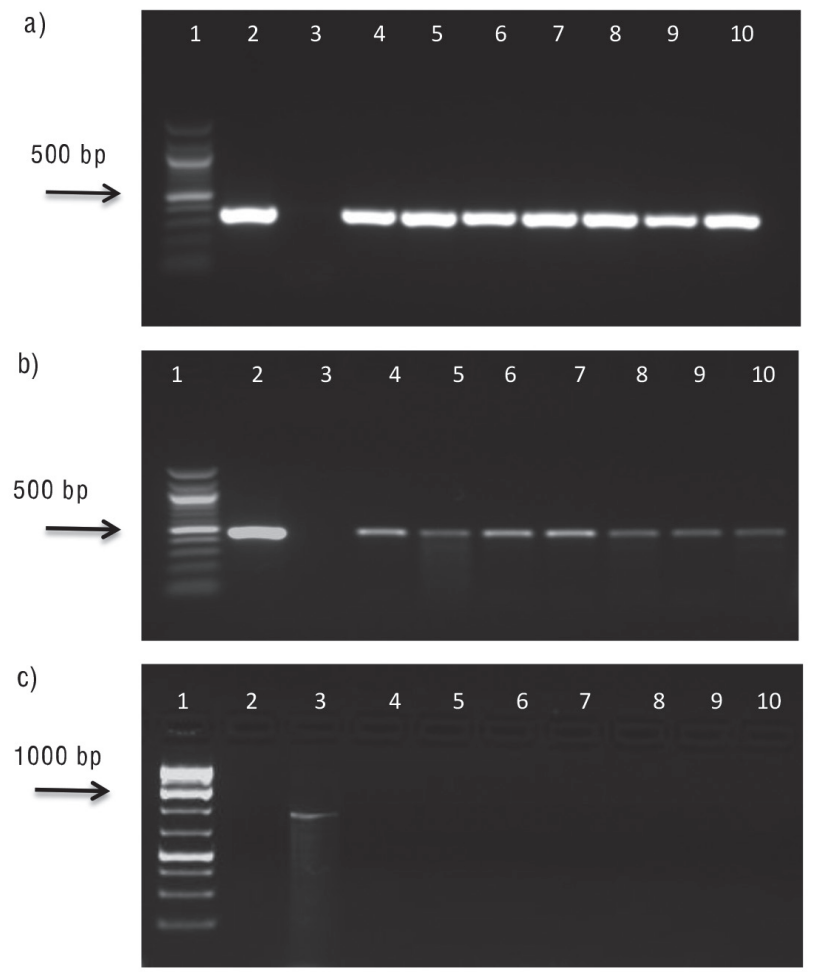

Fig. 3. Molecular evaluation of primary transformants: a) PCR assay showed the amplification of internal fragment (362 bp) of gusA. Lane $1=100 \mathrm{bp}$ plus ladder (Biolab), lane $2=$ positive control plasmid, lane $3=$ negative control, lanes $4-10=$ representative putative transgenic plants of each cultivar; b) PCR assay showed the amplification of internal fragment (450 bp) of npt/l gene. Lane $1=100 \mathrm{bp}$ plus ladder (Biolab), lane $2=$ positive control plasmid, lane $3=$ negative control, lanes 4-10=representative putative transgenic plants of each cultivar; and c) PCR results showed no amplification of ChvA gene in primary transformants indicating no Agrobacterium contamination. Lane $1=1 \mathrm{~kb}$ plus DNA ladder (Thermo Scientific), lane $2=$ negative control, lane $3=$ Agrobacterium chromosomal DNA as positive control, lanes 4-10=primary transformants

The primary transformants showed amplification of required bands of 362 bp of gus $A$ and 450 bp of nptll genes when subjected to PCR assays (Fig. $3 a$ and Fig. 3 b). In order to confirm the presence of any Agrobacterium contamination in primary transformants, PCR assays using ChvA gene (Agrobacterium chromosomal gene)-specific primers were also performed. Results revealed the absence of 890-bp amplicon, establishing the absence of any Agrobacterium contamination (Fig. 3c). Agrobacterium chromosomal genes are commonly used to test primary transformants $(15,25,26)$.

The harvested tubers from primary transformants were planted in the greenhouse (Fig. 4a) to confirm the expression of gusA gene in succeeding progeny by GUS histochemical assays (Fig. 4b). Besides that, PCR amplification of 450-bp partial fragment of nptll gene indicated the integration of T-DNA region in transgenic plants (Fig. 4c). First generation tubers were planted in the greenhouse to observe the introduced stability of introduced genes in subsequent progeny. GUS histochemical and PCR assays exhibited the gene transfer to subsequent progeny indicating the stability of the protocol.
The overall results showed that using proper hormonal combination in regeneration selection media can lead to increased regeneration frequency of potato cultivars. Using the above-mentioned protocol, insect- and herbicide-resistant potato lines expressing cry1Ac gene (27), cp4-epsps (28) and hairpin construct of insect metamorphosis-associated gene (29) were developed.

a)

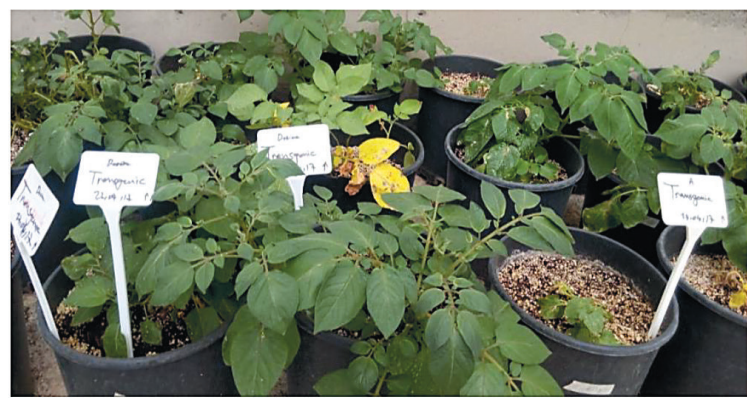

b)

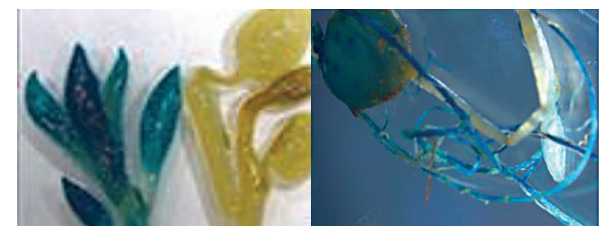

c)

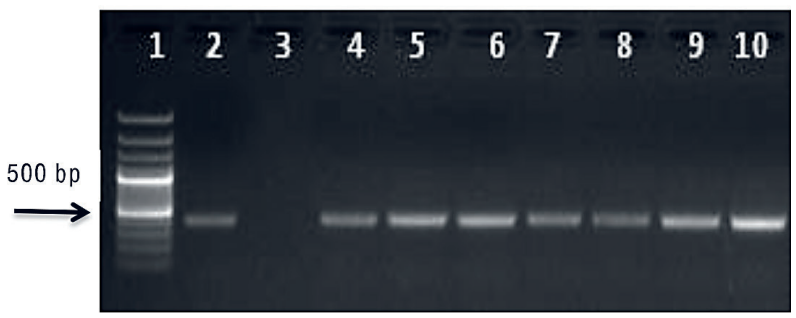

Fig. 4. Evaluation of transgenic plants from first tuber generation: a) plant samples in the greenhouse, b) GUS histochemical assay showed the expression of gusA gene in transgenic plants, and c) PCR assay showing amplification of 450-bp internal fragment of nptll gene in transgenic plants. Lane $1=100$ bp plus ladder (Thermo Scientific), lane 2 =positive control, plasmid DNA, lane 3 =negative control, lanes 4-13=first tuber generation transgenic plants of Lady Olympia and Désirée cultivars

\section{CONCLUSIONS}

This study presents suitable hormonal composition of the regeneration media, type of explants and most suitable cultivar for Agrobacterium-mediated potato transformation. According to the results, the use of internode explants is recommended as a generally better procedure taking all aspects of transformation and regeneration into account. Additionally, Lady Olympia cultivar appears to be superior to others in terms of transformation efficiency. Previous studies report Désirée as a suitable cultivar for genetic manipulations; however, based on the results of regeneration and transformation, Lady Olympia can also be recommended for future transformation procedures. 


\section{ACKNOWLEDGEMENTS}

The present work was completed during research activities of projects (Project No. 2150520 and 1150022) supported by Scientific and Technological Research Council of Turkey (Tübitak). I would like to thank Tahira Hussain for her help in collecting data, Dr Halil Toktay for providing access to microscope facilities and Prof. Dr Mehmet Emin Çalışkan for supplying seed tubers of cultivars used in the study. I am also thankful to Prof Dr Sebahattin Özcan, University of Ankara, for providing recombinant plasmid used in the study.

\section{SUPPLEMENTARY MATERIAL}

All supplementary material is available at www.ftb.com.hr.

\section{ORCID ID}

A. Bakhsh (1) https://orcid.org/0000-0003-3561-7863

\section{REFERENCES}

1. Gebru H, Mohammed A, Dechassa N, Belew D. Assessment of production practices of smallholder potato (Solanum tuberosum L.) farmers in Wolaita zone, southern Ethiopia. Agric Food Secur. 2017;6(1):31.

https://doi.org/10.1186/s40066-017-0106-8

2. Bagri DS, Upadhyay DC, Jain SK, Upadhyay CP. Biotechnological improvement of nutritional and therapeutic value of cultivated potato. Front Biosci (Schol Ed). 2018;10(1):217-28. https://doi.org/10.2741/s510

3. Göre ME. Fungal seaborne pathogens infecting potatoes seed tubers from Turkey, 2011-2014. J Plant Dis Prot. 2017;124:539-51.

https://doi.org/10.1007/s41348-017-0091-y

4. Loebenstein G, Thottappilly G, Fuentes S, Cohen J. Virus and phytoplasma diseases. In: Loebenstein G, Thottappilly $\mathrm{G}$, editors. The sweetpotato. Dordrecht, The Netherlands: Springer; 2009. pp. 105-34.

https://doi.org/10.1007/978-1-4020-9475-0_8

5. Dje Y, Diallo HA. Detection and distribution of sweet potato feathery mottle virus in sweetpotato using membrane immunobinding assay. Afr J Biotechnol. 2005;4(7):717-23. https://doi.org/10.5897/AJB2005.000-3131

6. Halterman D, Guenthner J, Collinge S, Butler N, Douches D. Biotech potatoes in the 21st century: 20 years since the first biotech potato. Am J Potato Res. 2016;93:1-20.

https://doi.org/10.1007/s12230-015-9485-1

7. Hwang HH, Yu M, Lai EM. Agrobacterium-mediated plant transformation: Biology and applications. The Arabidopsis Book. 2017;15:e0186. https://doi.org/10.1199/tab.0186

8. Ahmed HA, Barpete S, Akdogan G, Aydin G, Sancak C, Ozcan S. Efficient regeneration and Agrobacterium tumefaciens mediated genetic transformation of potato (Solanum tuberosum L.). Fresen Environ Bull. 2018;27(5):3020-7.

9. Cingel $A$, Vinterhalter B, Vinterhalter D, Ćalić-Dragosavac D, Smigocki A, Ninković S. Agrobacterium-mediated transformation of two Serbian potato cultivars (Solanum tuberosum L. cv. Dragačevka and cv. Jelica). Afr J Biotechnol. 2010;9(30):4644-50.

https://doi.org/10.5897/AJB09.1241

10. Vinterhalter D, Zdravković-Korać S, Mitić N, Dragićević I, Cingel A, Raspor M, Ninković S. Protocols for Agrobacterium-mediated transformation of potato. Fruit Veg Cereal Sci Biotech. 2008;2:1-5.

11. Beaujean A, Sangwan RS, Lecardonnel A, Sangwan-Norreel BS. Agrobacterium-mediated transformation of three economically important potato cultivars using sliced internodal explants: An efficient protocol of transformation. J Exp Bot. 1998;49(326):1589-95. https://doi.org/10.1093/jxb/49.326.1589

12. Hayta S, Smedley MA, Demir SU, Blundell R, Hinchliffe A, Atkinson N, Harwood WA. An efficient and reproducible Agrobacterium-mediated transformation method for hexaploid wheat (Triticum aestivum L.) Plant Methods. 2019;15(1):121.

https://doi.org/10.1186/s13007-019-0503-z

13. Bakhsh A, Hussain T, Caliskan ME. A promising and cost effective surface sterilizing method for sweet potato (Ipomoea batatas L.) cultivated in open environment. Fresen Environ Bull. 2017;26(4):3062-7.

14. Murashige T, Skoog F. A revised medium for rapid growth and bioassays with tobacco tissue cultures. Physiol Plant. 1962;15(3):473-97.

https://doi.org/10.1111/j.1399-3054.1962.tb08052.x

15. Nester EW. Agrobacterium: Nature's genetic engineer. Front Plant Sci. 2015;5:730.

https://doi.org/10.3389/fpls.2014.00730

16. Statistix v. 8.1 analytical software, Tallahassee, FL, USA; 2003. Available from: https://statistix.informer.com/8.1/.

17. Chetty VJ, Ceballos N, Garcia D, Narváez-Vasquez J, Lopez W, Orozco-Cárdenas ML. Evaluation of four Agrobacterium tumefaciens strains for the genetic transformation of tomato (Solanum lycopersicum L.) cultivar Micro-Tom. Plant Cell Rep. 2013;32(2):239-47.

https://doi.org/10.1007/s00299-012-1358-1

18. Bakhsh A, Dinc T, Hussain T, Demirel U, Aasim M, Çalışkan ME. Development of transgenic tobacco lines with pyramided insect resistant genes. Turk J Biol. 2018;42(2):174-86. https://doi.org/10.3906/biy-1710-71

19. Bakhsh A, Anayol E, Ozcan SF. Comparison of transformation efficiency of five Agrobacterium tumefaciens strains in Nicotiana tabacum L. Emir J Food Agric. 2014;26(3):259-64. https://doi.org/10.9755/ejfa.v26i3.16437 
20. Banerjee AK, Prat S, Hannapel DJ. Efficient production of transgenic potato (S. tuberosum L. ssp. andigena) plants via Agrobacterium tumefaciens-mediated transformation. Plant Sci. 2006;170(4):732-8.

https://doi.org/10.1016/j.plantsci.2005.11.007

21. Ducreux LJM, Morris WL, Taylor MA, Millam S. Agrobacterium-mediated transformation of Solanum phureja. Plant Cell Rep. 2005;24(1):10-4. https://doi.org/10.1007/s00299-004-0902-z

22. De Block M. Genotype-independent leaf disc transformation of potato (Solanum tuberosum) using Agrobacterium tumefaciens. Theor Appl Genet. 1988;76(5):767-74. https://doi.org/10.1007/BF00303524

23. Veale MA, Slabbert MM, Van Emmenes L. Agrobacterium-mediated transformation of potato cv. Mnandi for resistance to the potato tuber moth (Phthorimaea operculella). South Afr J Bot. 2012;80:67-74.

https://doi.org/10.1016/j.sajb.2012.02.007

24. Frary A, Earle ED. An examination of factors affecting the efficiency of Agrobacterium-mediated transformation of tomato. Plant Cell Rep. 1996;16(3-4):235-40.

https://doi.org/10.1007/BF01890875
25. Nain V, Jaiswal R, Dalal M, Ramesh B, Kumar PA. Polymerase chain reaction analysis of transgenic plants contaminated by Agrobacterium. Plant Mol Biol Rep. 2005;23(1):59-65. https://doi.org/10.1007/BF02772647

26. De Buck S, De Wilde C, Van Montagu M, Depicker A. T-DNA vector backbone sequences are frequently integrated into the genome of transgenic plants obtained by Agrobacterium-mediated transformation. Mol Breed. 2000;6:459-68. https://doi.org/10.1023/A:1026575524345

27. Amiri AN, Bakhsh A. An effective pest management approach in potato to combat insect pests and herbicide. 3 Biotech. 2019;9(1):16. https://doi.org/10.1007/s13205-018-1536-0

28. Bakhsh A, Hussain T, Rahamkulov I, Demirel U, Çalışkan ME. Transgenic potato lines expressing CP4-EPSP synthase exhibit resistance against glyphosate. Plant Cell Tiss Organ Cult. 2020;140:23-34. https://doi.org/10.1007/s11240-019-01708-1

29. Hussain T, Aksoy E, Çalışkan ME, Bakhsh A. Transgenic potato lines expressing hairpin RNAi construct of molting-associated $E c R$ gene exhibit enhanced resistance against Colorado potato beetle (Leptinotarsa decemlineata, Say). Transgenic Res. 2019;28(1):151-64. https://doi.org/10.1007/s11248-018-0109-7 